\title{
O ESTÚDIO DE TELEVISÃO E A EDUCAÇÃO DA MEMÓRIA*
}

Milton José de AlmeidA*

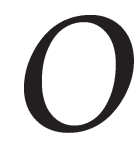

estúdio de televisão lembra-nos as diversas tradições de arranjo, guarda e manipulação de documentos, figuras de pessoas, objetos, pinturas.

Há uma secular tradição de locais da memória, locais em que se depositam objetos, pinturas, textos... para que ali guardados se tornem inesquecíveis e possam reviver a cada instante em que o olhar de alguém vivo os iluminar, como quando ligamos a televisão.

Também as cidades com suas casas, ruas, edifícios, suas ruínas, coisas guardadas em cada cômodo, cada armário e as pessoas que transitam por elas são locais da memória nos quais a História está sempre à espreita para ser chamada à vida e ser refeita constantemente.

Mas podemos lembrar de outros locais, mais intencionais, menos amplos. Como os famosos estúdios da memória que surgiram no Renascimento.

Giulio Camillo inventou talvez o mais excitante desses dispositivos, o Teatro da Memória: uma estrutura de madeira apresentada em Veneza, depois em Paris.

Num pequeno livro, ditado a um amigo antes de morrer, $A$ idéia do Teatro (1550), explica sua construção e seu funcionamento: um edifício que permitiria a entrada de um ou dois indivíduos de cada vez. Em seu interior haveria uma variedade de imagens, figuras, textos, ornamentos organizados em várias ordens e graus.

Ao entrar nele, o espectador ficaria num ponto do palco e daí olharia para o auditório, vazio de pessoas, evidentemente. Imagens,

* Resenha do livro de Laura Maria Coutinho (Brasília: Plano, 2003. 139p.).

** Professor da Faculdade de Educação da UNICAmp e coordenador do Laboratório de Estudos Audiovisuais (OlHO).E-mail:mja@directnet.com.br

Educ. Soc., Campinas, vol. 25, n. 86, p. 269-272, abril 2004 
O Estúdio de televisão e a educação da memória

textos, símbolos estariam colocados em diferentes níveis ou graus, em sete escadas ou rampas que sairiam de entre sete pilares, os pilares da Sabedoria de Salomão. Cada uma dessas escadas representaria a história do pensamento divino.

No primeiro grau deveriam estar as "sete medidas essenciais" representadas pelos sete planetas conhecidos e que foram as Primeiras Causas da Criação e das quais todas as coisas dependiam. O grau mais alto do Teatro era dedicado a todas as artes, tanto nobres quanto vis, e era representado por Prometeu que roubou a tecnologia do fogo dos deuses.

A circulação do pensamento humano nesse desenho geométrico, nessa alegoria da memória, segundo determinadas regras, permitiria ao homem apropriar-se de todo o conhecimento, ou seja, tornar-se divino.

Para além da beleza estética e intelectual desse Teatro da Memória, devemos perguntar sobre a sua política: $\mathrm{O}$ que deve ter a dignidade de tornar-se memória, qual poder decide o que será a memória? Quem deve permanecer? Quem merece ser lembrado? Normalmente esse "quem" não é propriamente uma pessoa, mas imagens de pessoas, de objetos, de lugares, de documentos, aquilo que não tem mais memória, pois a memória é atributo de quem está vivo.

O que seria essa memória que se estabelece após a morte em imagens, textos e objetos que deixam seus locais onde tiveram sentido e migram para outros. Talvez estejam migrando de algo que designaríamos como "ao vivo", um tempo presente contínuo da memória, para o espaço dos fragmentos da memória, um tempo descontínuo de imagens de um presente já passado, gravado, reunido e catalogado num teatro da memória, num estúdio de televisão. Diz Agostinho, no De trinitate (XIV, 8, 1), sobre a presença da imagem de Deus na alma humana:

São coisas que se encontram em determinados lugares ou que se passaram no tempo, se bem que neste último caso não se trate das coisas mesmas, mas de seus sinais que, vistos e ouvidos, fazem saber que essas coisas existiram e se passaram. Esses sinais se encontram em determinados lugares, como os túmulos e outros monumentos, ou nos escritos dignos de fé (...), ou na alma daqueles que já os conhecem (...).

Essas poucas anotações anteriores nos servem para chamar a atenção para o fato de que o estúdio de televisão contemporâneo é herdeiro de uma história de produção e reprodução da memória. E, 
mais que isso, persiste nele um processo secular de fabricação estética e política de imagens agentes feitas para se tornarem inesquecíveis, uma educação visual da memória.

Essa arte e essa educação se assentam num dos instrumentos mais importantes de fabricação de imagens: a perspectiva, um processo geométrico e matemático de ilusão visual, desenvolvido na Renascença e que persiste na tecnologia das atuais câmeras fotográficas e televisivas.

Essa poderosa técnica de captação, construção, interpretação e reprodução do real é também técnica de amestramento da tensão entre a experiência subjetiva e complexa do mundo de cada pessoa e o "real" objetivo e verificável garantido pela transmissão em perspectiva visual. Um desencantamento do mundo e um encantamento com o real, a sua sacralização.

Assim, as imagens na televisão não se apresentam como simples evocação da realidade, mas principalmente desejam entranhar-se como presença no universo humano e fazer parte da vida social.

O leitor já deve ter percebido o quanto estamos distantes da visão superficial da televisão sob o prisma simplista da comunicação e expressão...

Os signos e as imagens em movimento na transmissão televisiva não têm somente a ambição de estabelecer uma comunicação com os espectadores, mas, mais que isso, simular um contato real e uma presença nos locais mesmos em que esses espectadores estão.

São momentos de um ritual profano: de um único centro político, o estúdio, a imagem irradia para muitos lugares. Ao mesmo tempo, um cerimonial de magia e realismo: multiplicado pela luz, um corpo singular e único, vivo ou morto, faz sua aparição viva em muitos e diferentes espaços.

No entanto, o estúdio, ao construir a ponte que o liga aos olhares, ouvidos e mentes de cada espectador, ao mesmo tempo ressalta a distância entre esses dois pontos. A via é de mão única, as imagens transmitidas, quer representem pessoas e objetos existentes ou não, são sempre afirmativas. No pólo do espectador a única ação possível é fazê-las desaparecer ao toque de um botão, o que não é um poder irrelevante, e que pode simular a sensação de que o consumidor de imagens tem a liberdade de escolha.

Educ. Soc., Campinas, vol. 25, n. 86, p. 269-272, abril 2004 
O Estúdio de televisão e a educação da memória

Ver o estúdio de televisão como estúdio da memória é também vê-lo como um local onde estão arquivadas e catalogadas as imagens da História previamente escolhidas e que serão oferecidas ao espectador. Imagens que foram cortadas, coladas e colocadas em seqüência, editadas, para apresentarem-se em movimento estético e político. Imagens fantásticas que encantam ou assustam enquanto fazem e refazem a memória.

Podemos pensar, por exemplo, nos telejornais como momentos diários em que, dentro de um estúdio da memória, imagens extraídas do real serão escolhidas para comporem, em estética e política, a memória do dia.

A edição dessas imagens, que dará sentido político aos diferentes fatos, escolhendo-os, seqüenciando-os e chamando a atenção para cada um separadamente, promove ao mesmo tempo o apagamento técnico e político das suas diferenças, pois transforma os fatos em pequenas unidades de informação, produtos visuais a serem consumidos. Ou um deslocamento da esfera da arte (diferença) para a esfera da massa (identidade), conforme F. Jameson em As sementes do tempo.

Se isso nos afasta da inteireza dos estúdios da memória renascentistas, também nos permite ver nesses estúdios da televisão a persistência da produção e reprodução de imagens agentes da memória contemporânea, um verdadeiro teatro da História.

O que lembrei acima e muito mais nos revela esse trabalho de Laura Coutinho.

Levado por uma escritura original e competente, o leitor caminha com a autora por recantos e salas do estúdio de televisão, acompanhado também por imagens e palavras do cinema e das artes visuais do movimento.

Desviando-se dos lugares tão comuns e repetitivos das análises sobre o assunto, a autora dialoga com a inteligência e a cultura do leitor, especialista ou não, especialmente aquele que esteja interessado numa interpretação nova e reveladora da cultura contemporânea de imagens em movimento. 